\title{
The genera Eriochrysis P. Beauv., Imperata Cirillo and Saccharum L. (Poaceae - Andropogoneae - Saccharinae) in the state of Rio Grande do Sul, Brazil
}

\author{
CASSIANO AIMBERÊ DORNELES WELKER ${ }^{1,2}$ and HILDA MARIA LONGHI-WAGNER ${ }^{1}$
}

(received: June 20, 2011; accepted: February 9, 2012)

\begin{abstract}
The genera Eriochrysis P. Beauv., Imperata Cirillo and Saccharum L. (Poaceae - Andropogoneae - Saccharinae) in the state of Rio Grande do Sul, Brazil). The subtribe Saccharinae belongs to the tribe Andropogoneae and comprises ca. 140 species in 13 genera, including Eriochrysis, Imperata and Saccharum. This work presents a survey of the species of these three genera in the state of Rio Grande do Sul. Intensive field collections were made in different physiographic regions of the state, as well as studies in several herbaria. The occurrence of three native species of each genus was confirmed in Rio Grande do Sul, in addition to sugar cane (Saccharum officinarum) that is cultivated in the region. Based on the material examined, Eriochrysis villosa is reported for the first time in the state of Paraná, Brazil. Identification keys for the species, descriptions, data on their geographical distributions, habitats and flowering and fruiting periods, as well as illustrations of important taxonomic characters are provided.
\end{abstract}

Key words - floristics, Gramineae, Southern Brazil, taxonomy

\section{INTRODUCTION}

The family Poaceae comprises ca. 800 genera and 10,000 species with cosmopolitan distributions (Watson $\&$ Dallwitz 1992). The subfamily Panicoideae represents about a third of all grass species and is formed by two large tribes, Andropogoneae and Paniceae, as well as other smaller tribes. Andropogoneae comprises ca. 90 genera and 1,060 species (Sánchez-Ken \& Clark 2010) in 11 subtribes (Clayton \& Renvoize 1986). One of these subtribes is Saccharinae, with ca. 140 species in 13 genera (Clayton \& Renvoize 1986), including Eriochrysis P. Beauv., Imperata Cirillo, and Saccharum L. These three genera share similar inflorescences a panicle bearing numerous alternate racemes on an elongated central axis.

Eriochrysis includes ca. seven species distributed mainly in tropical regions (Filgueiras \& Lerina 2001a), of which six are cited for Brazil (Swallen 1966, Filgueiras 2010a). This genus is characterized mainly by inflorescences with golden-brown to light-brown trichomes and heterogamous spikelets: a sessile spikelet with a bisexual flower, and a pedicelled spikelet with a pistillate flower. The genera Imperata and Saccharum, on the other hand, have homogamous spikelets, with both spikelets of the pair having bisexual flowers.

\footnotetext{
1. Universidade Federal do Rio Grande do Sul. Departamento de Botânica. Av. Bento Gonçalves, 9500, Bloco IV, Prédio 43432, Campus do Vale, Bairro Agronomia, 91501-970 Porto Alegre, RS, Brazil

2._Corresponding author: cassiano_welker@yahoo.com.br
}

Imperata comprises ca. nine species found mainly in tropical and warm temperate regions (Flores 2001), four of which occur in Brazil (Filgueiras 2010b). This genus is characterized by having inflorescences with white trichomes, and racemes with persistent rachises. Both spikelets of the pair are short-pedicelled and fall off individually at maturity; the rachis internodes and pedicels remain with the inflorescence. Eriochrysis and Saccharum, in contrast, have disarticulating racemes and one sessile and one pedicelled spikelet at each rachis node, the pedicelled spikelet falls off first at maturity, the sessile spikelet falls off together with a rachis internode and the pedicel.

The genus Saccharum, in a broad sense, including the species of Erianthus Michx., comprises ca. 40 species distributed throughout tropical and subtropical regions of the world (Clayton \& Renvoize 1986, Webster \& Shaw 1995). Three native species of Saccharum occur in Brazil (Filgueiras 2010c). Some authors accept Erianthus separate from Saccharum, with approximately 28 species occurring in the Americas, Africa, Europe, and Asia (Mukherjee 1958, Molina 1981, Nicora \& Rúgolo de Agrasar 1987, Watson \& Dallwitz 1992). The circumscriptions of Saccharum and Erianthus are still controversial, although genetic studies seem to indicate that these taxa should be treated as independent genera (Besse et al. 1997, Nair et al. 2005, Selvi et al. 2006). Phylogenetic analyses performed by Hodkinson et al. (2002) found no support for this division, but these authors included only few species of Erianthus. As there have been no conclusive phylogenetic studies, Saccharum is accepted here in a broad sense, as recently 
adopted by Filgueiras (2010c). The species of the genus have inflorescences with white, cream, or pink trichomes, often included in a spathe formed by the sheath of the apical leaf.

This paper presents a survey of the species of the genera Eriochrysis, Imperata and Saccharum in the state of Rio Grande do Sul, Brazil, as a contribution to floristic, phytosociological, ecological, and phylogenetic studies. Analytical keys for species identification, descriptions, illustrations, as well as data on geographical distribution and habitats are provided.

\section{MATERIAL AND METHODS}

Fifteen field trips were undertaken from October/2008 to December/2010 in different physiographic regions in the state of Rio Grande do Sul, Brazil (Fortes 1959). The material collected was deposited in the ICN herbarium. Specimens deposited in the BLA, CNPO, HAS, HUCS, HUI, HVAT, ICN, PACA, PEL, RSPF, and SMDB herbaria (acronyms according to Thiers 2011 and RBH 2011) were also analyzed.

Species descriptions are based on material from Rio Grande do Sul and consider mainly the characters used in the identification keys.

Data on the geographical distributions of the species provided here are based on the literature. The species distributions in Rio Grande do Sul, as well as data on habitat and flowering and fruiting periods, are all based on collected material and the herbarium exsiccates we analyzed. The physiographic regions cited for Rio Grande do Sul follow Fortes (1959). Only one specimen from each municipality is cited in the selected material to better demonstrate the distribution of each taxon in Rio Grande do Sul. All of the material examined is cited in the list of exsiccates.

The habit and a pair of spikelets are illustrated for each species. In some cases, other details are included to illustrate the morphological variability of the taxon and aid in its identification. The illustrations of the reproductive structures were prepared by the first author and the illustrations of the habits and inflorescences by Anelise Scherer.

\section{RESULTS AND DISCUSSION}

The occurrences of three native species of each of the genera Eriochrysis, Imperata and Saccharum were confirmed in Rio Grande do Sul, representing, respectively, 50,75 and $100 \%$ of the species of these genera cited for Brazil by Filgueiras (2010a, b, c) and Swallen (1966). In addition to these native species, Saccharum officinarum L. (sugar cane) is cultivated in the region.

Based on the material examined, Eriochrysis villosa Swallen represents a new record for the state of Paraná, Brazil.

\section{Eriochrysis P. Beauv., Ess. Agrostogr. 8. 1812.}

Perennial, caespitose with short, thick rhizomes; nodes pilose. Leaf blades linear to linear-lanceolate; ligule membranous-ciliate. Inflorescence a contracted to slightly open panicle, bearing numerous alternate racemes on a central axis. Racemes differentiated into nodes and internodes, disarticulating at the nodes, densely to sparsely pilose, trichomes golden-brown to light-brown. Spikelets paired at each node of the rachis, one sessile and one pedicelled, heterogamous, the pedicelled spikelet falling off first at maturity, the sessile falling off together with a rachis internode and the pedicel. Spikelets with 2 anthecia; 2 glumes chartaceous, the lower two-keeled, the upper onekeeled, anthecia hyaline. Sessile spikelet awnless, with bisexual flower; lower anthecium neuter, lemma present, palea lacking; upper anthecium with bisexual flower, lemma present, palea lacking; stamens 3 . Pedicelled spikelet awnless, similar to the sessile, but with pistillate flower.

About seven species distributed mainly in tropical regions of the Americas, Africa, and India (Filgueiras \& Lerina 2001a). The genus is represented by three species in Rio Grande do Sul.

Key to the species of Eriochrysis in Rio Grande do Sul

1. Inflorescence sparsely pilose, spikelets apparent among the trichomes. Sessile spikelet with basal trichomes reaching up to $1 / 2$ of its length; lower glume sparsely pilose towards the apex. Sessile spikelet 4.5-6.5 $\mathrm{mm}$ long, rarely $4 \mathrm{~mm}$ long in the same inflorescence 1.2. E. holcoides

1. Inflorescence densely pilose, with most of each spikelet hidden among the trichomes. Sessile spikelet with basal trichomes longer, subequal or reaching $2 / 3$ of its length, rarely reaching only $1 / 2$ of its length; lower glume densely pilose towards the apex. Sessile spikelet 1.8-4.5 mm long, rarely up to $5 \mathrm{~mm}$ long in the same inflorescence.

2. Lower glume of sessile spikelet with apex obtuse to truncate, trilobed. Sessile spikelet 1.8-3.5 mm long 1.1. E. cayennensis

2. Lower glume of sessile spikelet with apex acute to subacute, non-lobed or with inconspicuous lobes. Sessile spikelet 3-4.5 $\mathrm{mm}$ long, rarely up to $5 \mathrm{~mm}$ long in the same inflorescence 1.3. E. villosa 
Swallen (1966) distinguished Eriochrysis cayennensis P. Beauv. from E. villosa and E. glabrifolia Swallen by the color of the trichomes in their inflorescences, dark-brown in the former and lightbrown in the latter species. Eriochrysis glabrifolia, cited by Swallen (1966) for the states of Santa Catarina and Paraná, was considered a synonym of $E$. cayennensis by Smith et al. (1982), Filgueiras (2003a), and Morrone et al. (2008). The analysis of the material collected in Rio Grande do Sul revealed that this feature varies in both E. cayennensis and E. villosa, hence it is not a good taxonomic character for these species.

\subsection{Eriochrysis cayennensis P. Beauv., Ess. Agrostogr.} 8, t. 4, f. 11. 1812.

Figures 1-4

Plants (30-)45-180 cm high. Leaf sheaths glabrous or glabrescent, less commonly villous near the apex; blades 9-38 $\mathrm{cm} \times 4-8 \mathrm{~mm}$, glabrous or glabrescent, less commonly villous on both surfaces, with dense tufts of trichomes 4-12 mm long at the base of the adaxial surface, behind the ligule; ligule 1-2.3 mm long. Inflorescence contracted, (5-)6-23 cm long, densely pilose, with most of each spikelet hidden among the golden-brown trichomes. Sessile spikelet 1.8-3.5 mm long; lower glume glabrous on back, subdensely pilose on margins, and densely pilose towards the apex, with apex obtuse to truncate, trilobed; upper glume with apex subacute to obtuse, non-lobed; basal trichomes longer or subequal to the spikelet, less commonly reaching only $2 / 3$ of its length. Pedicelled spikelet 1.5-2.2 mm long. Caryopsis 0.7-1 mm long.

United States to Argentina and Brazil (Filgueiras 2003a). Brazil: throughout most of the country (Smith et al. 1982, Filgueiras 2010a). Rio Grande do Sul: in most physiographic regions, in marshlands and wet grasslands. Collected with flowers and fruits mainly from September to April.

Eriochrysis cayennensis is the most common species of its genus in Rio Grande do Sul and resembles E. villosa, but differs from the latter by having the apex of the lower glume of the spikelets obtuse to truncate, trilobed (figure 4); this same structure in E. villosa is acute to subacute and non-lobed (figure 7), or with inconspicuous lobes (figure 8). The trilobed apex of the lower glume of $E$. cayennensis is usually much more evident in the sessile spikelet than in the pedicelled spikelet.

Beauvois (1812) described E. cayennensis as having obtuse glumes, but without making reference to or illustrating the presence of lobes at their apex. However, in the Flora of the Guianas (the country in which the type material was collected) this species is described as having the apex of the lower glume of the sessile spikelet obtuse to truncate, minutely trilobed (Judziewicz 1990). It is likely that Beauvois (1812) did not notice this detail when describing the species, since the apex of the glumes is usually hidden by large numbers of trichomes. Burkart \& Toursarkissian (1969) illustrated the lower glume of E. cayennensis with its apex typically trilobed, while Smith et al. (1982) described this species as having glumes obtuse or lobed at the apex.

Eriochrysis villosa was described by Swallen (1966) as having villous leaves and acute glumes, based on the specimen Swallen 8237 collected in the state of Santa Catarina and deposited in the US herbarium. An isotype of this material was examined at the PEL herbarium. Two other collections were cited in the protologue of this species, both collected by B. Rambo in Rio Grande do Sul, with no reference to the herbarium in which they were deposited. These two collections were analyzed at the PACA herbarium. One of them (Rambo 52049) does not match the original description, since the apex of the lower glume of the sessile spikelet is obtuse to truncate, trilobed, and the leaves glabrous, corresponding, therefore, to E. cayennensis. The other collection (Rambo 36476 ) includes two plants on the same herbarium sheet: one corresponding to E. cayennensis, with the apex of the lower glume trilobed, and glabrous leaves, whereas the other plant matches the original description of $E$. villosa, with the apex of the lower glume acute, non-lobed, and villous leaves, as in the isotype of the species (Swallen 8237 - PEL). The specimen Rambo 52049 (PACA) was identified by J. R. Swallen, but there is no information about whether the author analyzed the Rambo 36476 material deposited in the same herbarium.

Several specimens collected in Rio Grande do Sul show the apices of the lower glumes of their sessile spikelets (figure 7) and the indumentum of their leaves as typical of E. villosa. However, the apices of the lower glumes of the sessile spikelets are subacute in a considerable number of specimens, with three inconspicuous lobes (figure 8), and the leaves are glabrescent. This material is being accepted in this work within the variability of $E$. villosa. It is possible, however, that the specimens with intermediate morphology are natural hybrids between $E$. villosa and E. cayennensis.

Some specimens of E. cayennensis (e.g. LonghiWagner \& Boldrini $1710-$ ICN) were collected in the same locality and on the same day as plants of E. villosa (Longhi-Wagner \& Boldrini $1705-\mathrm{ICN}$ ), indicating that these two taxa occur sympatrically in Rio Grande do Sul. 

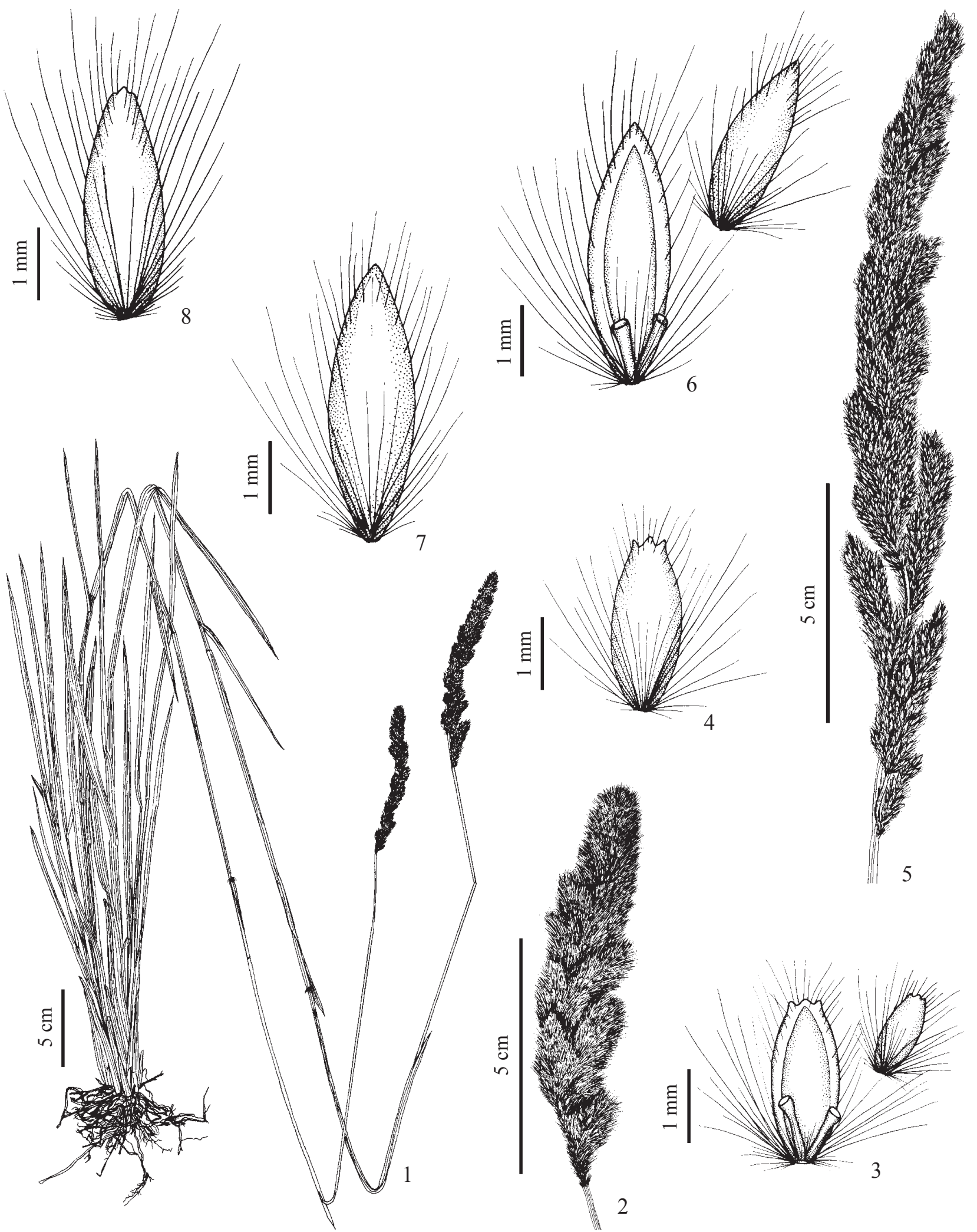

Figures 1-8. 1-4. Eriochrysis cayennensis. 1. Habit (Longhi-Wagner \& Welker 10781). 2. Inflorescence (Welker 183). 3. Pair of spikelets, pedicel, and rachis internode. 4. Lower glume of the sessile spikelet with apex obtuse to truncate, trilobed (LonghiWagner \& Welker 10781). 5-8. Eriochrysis villosa. 5. Inflorescence. 6. Pair of spikelets, pedicel, and rachis internode. 7. Lower glume of the sessile spikelet with apex acute, non-lobed (Welker 328). 8. Lower glume of the sessile spikelet with apex subacute, with inconspicuous lobes (Welker 182). 
It is interesting to note, however, that specimens typical of E. villosa were also analyzed from Santa Catarina and Paraná, whereas all analyzed collections of this species complex from other Brazilian states, as well as from other South and Central America countries, have the lower glume typical of E. cayennensis (see selected material).

Smith et al. (1982) accepted both E. villosa and E. cayennensis, whereas Filgueiras (2003a) considered E. villosa as a probable synonym of E. cayennensis. Due to this controversy, and considering the subtle morphological differences between these species, we are conducting molecular and cytogenetic analysis to better define their circumscriptions.

Material selected: BRAZIL. Rio Grande do Sul: Arroio do Sal, RS-389, 22-XII-2009, CAD Welker 253 (ICN); Bagé, BR-153, near km 116, 21-IV-1988, HM Longhi-Wagner \& II Boldrini 1710 (ICN); Bom Jesus, RS-110, 14-I-2009, HM Longhi-Wagner \& CAD Welker 10675 (ICN); Cacequi, Sangão do Macaco Branco, 28IX-1983, O Bueno s.n. (ICN 92620); Cachoeira do Sul, BR-403, 7-X-2008, HM Longhi-Wagner \& CAD Welker 10558 (ICN); Cambará do Sul, RS-020, near km 133, 28-II-2010, CAD Welker 290 (ICN); Canela, Sítio Felix Garcez, 30-III-2009, HM Longhi-Wagner \& CAD Welker 10772 (ICN); Caxias do Sul, 19-II-2000, A Kegler 693 (HUCS); Cidreira, Lagoa da Antônia, 14-XI-2008, CAD Welker 183 (ICN); Eldorado do Sul (Guaíba), Estação Experimental Agronômica, 8-III-1962, V Fagundes s.n. (BLA 2416); Jaquirana to São Francisco de Paula, 20II-1952, B Rambo 52049 (PACA); Nonoai, III-1945, B Rambo 28475 (PACA); Passo Fundo, Valinha, 17-XII1945, JR Swallen 7752 (PEL); Pelotas, Horto Florestal, 23-IV-1946, JR Swallen 9196 (PEL); Porto Alegre, Morro Santana, 14-IX-2005, CAD Welker 117 (ICN); Santa Maria, Estação Experimental de Silvicultura, 28-II-1956, OR Camargo 30 (PACA); São Francisco de Assis to São Vicente do Sul, RS-241, near km 10, 9-I-2009, CAD Welker 211 (ICN); São Francisco de Paula, 30-III-2009, HM Longhi-Wagner \& CAD Welker 10781 (ICN); São Gabriel, Estação Experimental de Forrageiras, 10-I-1969, A Pott s.n. (BLA 9664); São José dos Ausentes, 2-III-2010, CAD Welker 305 (ICN); São Leopoldo, 10-III-1947, E Henz s.n. (PACA 36965); Terra de Areia, 15-IV-1989, PC Neves s.n. (ICN 83445); Torres, Itapeva, 11-V-2004, HM Longhi-Wagner $9100 a(\mathrm{ICN})$.

Additional material selected: BOLIVIA. BENI: Yacuma, $50 \mathrm{~km}$ from San Borja, on the road to San Ignacio, 26-II-1987, S Renvoize 4601 (K). SANTA CRUZ: Ichilo, $4 \mathrm{~km}$ from Buenavista, on the road to
Carandá, 24-II-1998, JRI Wood \& DJ Goyder 13071 (K). BRAZIL. GoIÁs: Goiatuba, Venda Seca, 24-I-1996, MR Pietrobom-Silva 2703 (ICN). Mato Grosso DO SuL: Três Lagoas, Fazenda Barreirinho, 30-VII-1983, F Barros 880 (ICN). Minas Gerais: Juiz de Fora, São Pedro, 2-II-1988, L Krieger 23809 (ICN). PARÁ: Região dos Tiriós, Paru do Oeste river, 19-III-1962, Fittkau \& D Coelho s.n. (INPA 12829). PARANÁ: Ponta Grossa, 28I-1946, JR Swallen 8296 (PEL). Roraima: Boa Vista, road to Serra Grande, 4-VIII-1986, ELS Silva et al. 668 (INPA). Santa Catarina: Florianópolis, Ilha de Santa Catarina, Lagoa da Conceição, 12-IX-1985, ML Souza 778 (HUCS). São PaUlo: Itirapina, 27-I-1996, HM Longhi-Wagner 3315 (ICN). GUATEMALA. SANTA RosA: Santa Rosa de Lima, I-1894, Heyde \& Lux 3564 (K). MEXICO. Sabana Palenque, Chis, 9-VII-1939, E Matuda 3750 (K). NICARAGUA. Zelaya: $12 \mathrm{~km}$ from Sisín, 13-VII-1970, RW Pohl \& G Davidse 12308 (K). PARAGUAY. Misiones: Santiago, Estância La Soledad, 27-IV-1961, TM Pedersen 6007 (K). SAN PEDro: Lima, Estância Carumbé, 1967, TM Pedersen $8605(\mathrm{~K})$.

Plants of Eriochrysis cayennensis and E. villosa on the same herbarium sheet: BRAZIL. Rio GRANDE DO SUL: Cambará do Sul to São Francisco de Paula, II-1948, B Rambo 36476 (PACA).

1.2. Eriochrysis holcoides (Nees) Kuhlm., Comm. Lin. Telegr., Bot. 67(Bot. 11): 89. 1922.

Anatherum holcoides Nees, Agrostologia brasiliensis, in Mart., Fl. Bras. Enum. P1. 2: 324. 1829.

Figures 9-12

Plants (32-)46-115 cm high. Leaf sheaths glabrous or glabrescent; blades $11-43 \mathrm{~cm} \times 3-5 \mathrm{~mm}$, glabrous or glabrescent on both surfaces, with dense tufts of trichomes 2-7 $\mathrm{mm}$ long at the base of the adaxial surface, behind the ligule; ligule $0.7-1 \mathrm{~mm}$ long. Inflorescence contracted, 5-13 cm long, sparsely pilose, spikelets apparent among the light-brown trichomes. Sessile spikelet 4.5-6.5 $\mathrm{mm}$ long, rarely $4 \mathrm{~mm}$ long in the same inflorescence; lower glume glabrous on back, subdensely pilose on margins and sparsely pilose towards the apex, with apex acute to acuminate, non-lobed; upper glume with apex acute, non-lobed; basal trichomes up to $1 / 2$ of the length of the spikelet. Pedicelled spikelet 2.5$4 \mathrm{~mm}$ long. Caryopsis 1-1.2 mm long.

Colombia to Paraguay and Brazil (Filgueiras 2003a). Brazil: Mato Grosso and Bahia to Rio Grande do Sul (Smith et al. 1982). Rio Grande do Sul: Campos de Cima da Serra, less common in Encosta Superior do Nordeste 
and Litoral, in marshlands and wet grasslands. Collected with flowers and fruits from September to January.

Eriochrysis holcoides is not common in Rio Grande do Sul, differing from E. cayennensis and E. villosa mainly by its sparsely pilose inflorescence (figure 10) and plants generally less robust. Furthermore, the sessile spikelets of E. cayennensis and E. villosa are shorter than those of E. holcoides, being 1.8-3.5 mm and 3$4.5(-5) \mathrm{mm}$ long respectively.

Material selected: BRAZIL. Rio GRANDE Do SUL: Cambará do Sul, Fortaleza dos Aparados, 18-IX-2004, HM Longhi-Wagner et al. 9255 (ICN); Farroupilha, 10XI-1957, OR Camargo 2499 (PACA); Rio Grande, Est. Domingos Petrolini, 9-XI-1945, JR Swallen 7307 (PEL); São Francisco de Paula, RS-020, near km 110, 16-XI2010, CAD Welker 338 (ICN); São José dos Ausentes, 15-I-2009, HM Longhi-Wagner \& CAD Welker 10731 (ICN); Vacaria, Estação Experimental de Forrageiras, 16-IX-1971, JFM Valls 1593 (ICN).

1.3. Eriochrysis villosa Swallen, Phytologia 14(2): 90. 1966.

Figures 5-8

Plants (40-)52-160 cm high. Leaf sheaths villous, less commonly glabrous or glabrescent; blades 12 $34 \mathrm{~cm} \times 5-10 \mathrm{~mm}$, villous or glabrescent on both surfaces, with dense tufts of trichomes 3-10 mm long at the base of the adaxial surface, behind the ligule; ligule 0.8-1.5 mm long. Inflorescence contracted, 8$22 \mathrm{~cm}$ long, densely pilose, with most of each spikelet hidden among the golden-brown trichomes. Sessile spikelet 3-4.5 $\mathrm{mm}$ long, rarely up to $5 \mathrm{~mm}$ long in the same inflorescence; lower glume glabrous on back, subdensely pilose on margins and densely pilose towards the apex, with apex acute to subacute, non-lobed or with inconspicuous lobes; upper glume with apex subacute to obtuse, non-lobed; basal trichomes longer, subequal, or reaching $2 / 3$ of the length of the spikelet, rarely reaching $1 / 2$ of its length. Pedicelled spikelet 2-3.5 mm long. Caryopsis 0.8-1.2 mm long.

Southern Brazil, in Rio Grande do Sul, Santa Catarina (Swallen 1966, Smith et al. 1982), and Paraná. This is the first record of this species for the state of Paraná. Rio Grande do Sul: Campos de Cima da Serra and Litoral, less common in Encosta Superior do Nordeste, Planalto Médio, Missões and Campanha, in marshlands and wet grasslands. Collected with flowers and fruits mainly from November to April.

Eriochrysis villosa resembles E. cayennensis, being distinguished mainly by the apex of the lower glume of the sessile spikelet, as already discussed for $E$. cayennensis. In addition, plants of E. villosa commonly have villous leaves, or at least more densely pilose than E. cayennensis; glabrescent plants also occur, here identified as E. villosa by the apex of the lower glume of the sessile spikelet. This species also tends to have longer spikelets than E. cayennensis, but there is some overlap in this character.

Material selected: BRAZIL. Rio GRANDE Do Sul: Bagé, BR-153, near km 116, 21-IV-1988, HM LonghiWagner \& II Boldrini 1705 (ICN); Bom Jesus, II-1902, J Dutra 463 (ICN); Cambará do Sul to São Francisco de Paula, RS-020, 25-XI-2005, HM Longhi-Wagner 9920 (ICN); Caxias do Sul, 8-II-1955, B Rambo 56789 (PACA); Cidreira, 14-XI-2008, CAD Welker 182 (ICN); Esmeralda, Estação Ecológica de Aracuri, 3-XII-2002, J Mauhs s.n. (ICN 146284, PACA 87025); Júlio de Castilhos to Cruz Alta, 2-II-1971, ML Porto \& P Oliveira s.n. (ICN 9596); Osório, Atlântida Sul, BR-389, 22-XII-2009, CAD Welker 243 (ICN); São Francisco de Paula, Colinas de São Francisco, 30III-2009, HM Longhi-Wagner \& CAD Welker 10797 (ICN); São Luiz Gonzaga, BR-285, near km 577, $24-$ III-2010, CAD Welker 328 (ICN); Tramandaí, 5-XI1991, GC Coelho s.n. (HUI 2087); Tupanciretã, 15XI-1956, KH Mohrdieck 36 (BLA); Vacaria, Estação Experimental de Forrageiras, 22-III-1962, VR Froners.n. (BLA 3015).

Additional material selected: BRAZIL. PARANÁ: Jaguariaíva, Parque Estadual do Cerrado, 22-X-2000, $L$ von Linsingen 560 (ICN); Piraquara, Roça Nova, 20II-1946, JR Swallen 8658 (PEL); Tibagi, Parque Estadual do Guartelá, 4-XII-2003, MRB Carmo 450 (ICN). SANTA Catarina: Rio Caçador, 21-I-1946, JR Swallen 8237 (PEL - isotype of E villosa).

\section{Imperata Cirillo, Pl. Rar. Neapol. 2: 26. 1792.}

Perennial, caespitose with long, slender rhizomes; nodes glabrous. Leaf blades linear to linear-lanceolate; ligule membranous or membranous-ciliate. Inflorescence a contracted or loosely contracted panicle, bearing numerous alternate racemes on a central axis. Racemes differentiated into nodes and internodes, not disarticulating at the nodes, densely pilose, trichomes white. Spikelets paired at each node of the rachis, both short-pedicelled, pedicels unequal in length, homogamous, spikelets falling off individually at maturity, rachis internodes and pedicels persistent on the inflorescence. Spikelets with 2 anthecia; 2 glumes membranous, 3-9-nerved, equal or subequal, anthecia hyaline. Spikelets awnless, with 

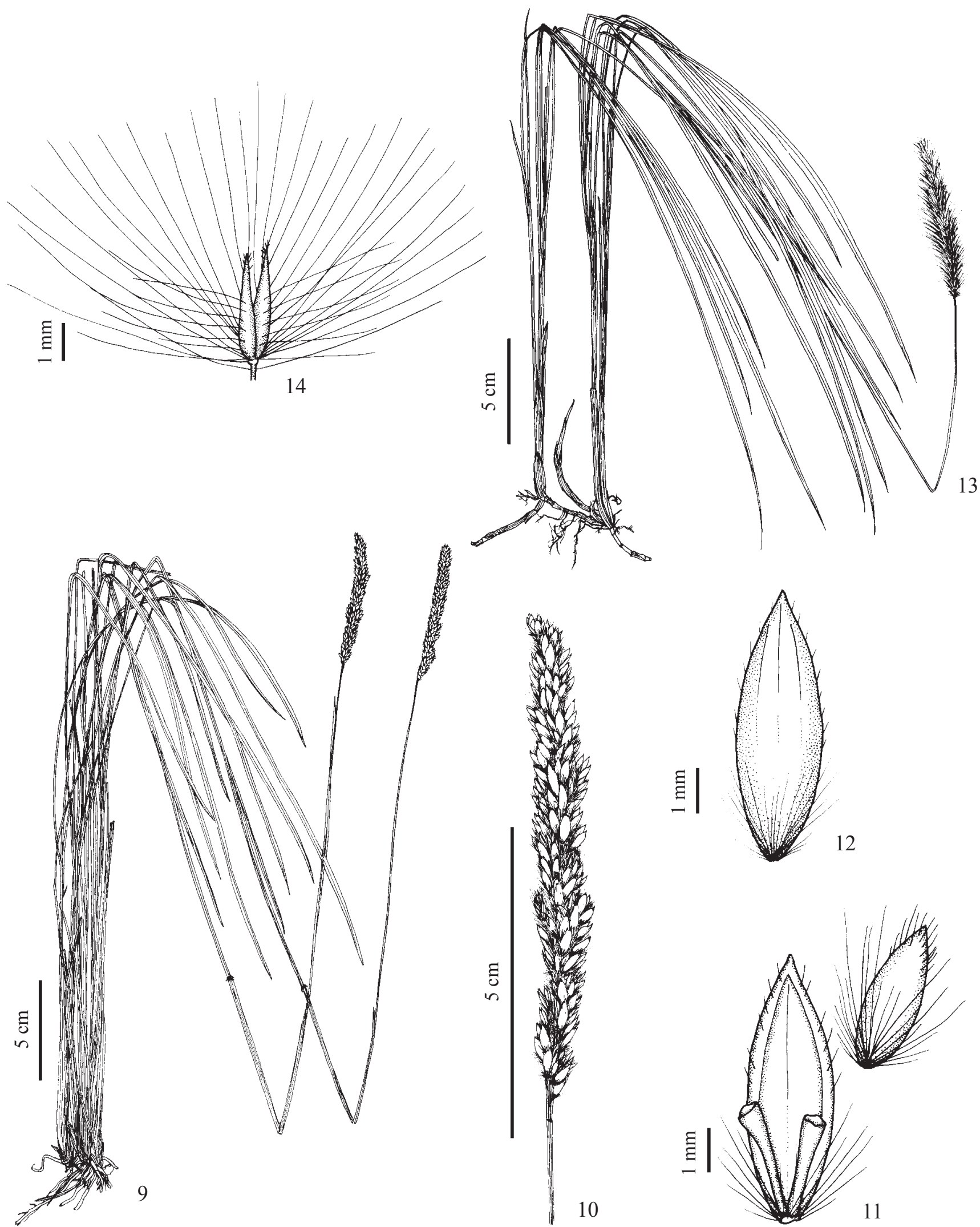

Figures 9-14. 9-12. Eriochrysis holcoides (Longhi-Wagner \& Welker 10731). 9. Habit. 10. Inflorescence. 11. Pair of spikelets, pedicel, and rachis internode. 12. Lower glume of the sessile spikelet. 13-14. Imperata brasiliensis (Welker 173). 13. Habit. 14. Spikelet. 
bisexual flower; lower anthecium neuter, lemma present, palea lacking; upper anthecium with bisexual flower, lemma present or lacking, palea present. Stamens 1-2.
About nine species distributed mainly in tropical and temperate regions of the world (Flores 2001). The genus is represented by three species in Rio Grande do Sul.

Key to the species of Imperata in Rio Grande do Sul

1. Inflorescence (23-)30-39 cm long, very rarely $12 \mathrm{~cm}$ long on the same plant; basal racemes divergent 2.2. I. contracta

1. Inflorescence 6-26 cm long; basal racemes adpressed.

2. Inflorescence 6-13(-15) cm long. Plants (25-)37-82(-92) cm high 2.1. I. brasiliensis

2. Inflorescence (10-)15-26 cm long. Plants (67-)85-145 cm high 2.3. I. tenuis

2.1. Imperata brasiliensis Trin., Mém. Acad. Imp. Sci. St.-Petersbourg, Ser. 6, Sci. Math. 2(3): 331. 1832. Figures 13-14

Plants (25-)37-82(-92) cm high. Leaf sheaths glabrous; blades (12-)17-43(-48) cm × (3.5-) 4-11 mm, glabrous on abaxial surface, glabrous or sparsely to subdensely pilose on adaxial surface, with trichomes 2-6 $\mathrm{mm}$ long at the base of adaxial surface, mainly on margins; ligule membranous-ciliate, 1.2-2.2 mm long. Inflorescence contracted, 6-13(-15) cm long, basal racemes 1.5-2.5(-3) cm long, adpressed. Spikelets (2.5-) 3-4 mm long; glumes with long silky trichomes. Stamen 1. Caryopsis $0.9-1.3 \mathrm{~mm}$ long.

United States to Argentina and Brazil (Filgueiras 2003b). Brazil: throughout most of the country (Smith et al. 1982). Rio Grande do Sul: Litoral, less common in Encosta do Sudeste, Depressão Central and Campos de Cima da Serra, in wet sandy fields, secondary dunes, and marshlands, occasionally in disturbed areas. Collected with flowers and fruits mainly from September to January.

Imperata brasiliensis is the most common species of this genus in Rio Grande do Sul. It is very similar to I. tenuis Hack., from which it is traditionally distinguished by the smaller stature of the plants and shorter inflorescences (Gabel 1982, Renvoize et al. 1998), but with overlaps in these dimensions. Several intermediate specimens collected in Rio Grande do Sul were analyzed, making it difficult to separate these taxa. A wide range of variation in stature and inflorescence size can be observed in a single population, as in the population of $I$. tenuis represented by the specimen Welker 219 (ICN), with plants 67-105 cm high and inflorescences 10-18 cm long. However, the lowest values are rarely found in I. tenuis, but are typical for I. brasiliensis.

Additionally, populations of I. brasiliensis are usually formed by sparsely distributed individuals that do not form clumps, usually with one to few floriferous culms, although the populations may occupy large areas. On the other hand, plants of I. tenuis often form clumps with several aggregate culms in dense populations that cover large areas. Although this feature is easily observed in the field, it generally cannot be detected with herbarium specimens as the clumps are often dismembered during preparation.

Due to the tenuous morphological boundaries between these species, we are presently conducting molecular analysis to better define their circumscriptions, including representatives of the variability observed in this species complex in relation to their habits, statures, and inflorescence lengths.

Material selected: BRAZIL. Rio GRANDE DO Sul: Arroio do Sal, Praia de Rondinha, 1-XII-2008, R Lerina \& GH Silveira 100 (ICN); Balneário Pinhal, Praia do Pinhal, 19-I-2010, CAD Welker 287 (ICN); Capão da Canoa to Praia de Atlântida, 2-V-1971, A Normann s.n. (BLA 8417); Capão do Leão, road to Horto Florestal Embrapa/UFPEL, 10-XI-2008, CAD Welker 158 (ICN); Cidreira, road to Nova Tramandaí, 22-XII-2010, HM Longhi-Wagner \& CAD Welker 10848 (ICN); Cristal, BR-116, 7-XII-1990, HM Longhi-Wagner et al. 2142 (ICN); Osório, Atlântida Sul, BR-389, 22-XII-2009, CAD Welker 249 (ICN); Palmares do Sul, road to Granja Vargas, 2-X-2009, HM Longhi-Wagner 10815 (ICN); Pelotas, Fazenda da Palma, 22-X-1945, JR Swallen 7125 (PEL); Rio Grande, Cassino, 12-XI-2008, CAD Welker 174 (ICN); Santa Vitória do Palmar, Praia do Hermenegildo, 11XI-2008, CAD Welker 173 (ICN); São José do Norte, 13-XI-2008, CAD Welker 176 (ICN); São Leopoldo, 6XI-1946, H Simas 35451 (PACA); Torres, Itapeva, 9VII-2005, C Palma 28 (ICN); Tramandaí, 9-IV-1997, C Teixeira \& BE Irgang s.n. (ICN 112070); Vacaria, Estação Experimental de Forrageiras, 15-XI-1962, $A$ Kappel \& VR Froner s.n. (BLA 2559); Xangri-lá, Praia de Atlântida, 10-IX-1972, JFM Valls 2144 (ICN). 
2.2. Imperata contracta (Kunth) Hitchc., Annual Rep. Missouri Bot. Gard. 4: 146. 1893.

Saccharum contractum Kunth in Humb., Bonpl. \& Kunth, Nov. Gen. Sp. 1: 182. 1816.

Figures 15-16

Plants (90-)102-165 cm high. Leaf sheaths glabrous; blades $24-50 \mathrm{~cm} \times 7-16 \mathrm{~mm}$, glabrous on abaxial surface, glabrous or sparsely pilose on adaxial surface, generally with trichomes $2-7 \mathrm{~mm}$ long at the base of adaxial surface, mainly on margins; ligule membranousciliate, 0.5-1.5 mm long. Inflorescence subcontracted, (23-)30-39 cm long, very rarely $12 \mathrm{~cm}$ long on the same plant, basal racemes (4-)4.5-7 cm long, divergent. Spikelets 2.3-3.2(-3.7) mm long; glumes with long silky trichomes. Stamen 1. Caryopsis 0.7-1 mm long.

Mexico to Argentina and Brazil (Filgueiras 2003b). Brazil: throughout most of the country (Smith et al. 1982). Rio Grande do Sul: Litoral and Encosta Inferior do Nordeste, in marshlands, wet grasslands, and disturbed areas, occasionally invasive in sugar cane and pineapple plantations. Collected with flowers and fruits throughout most of the year.

Imperata contracta is not common in Rio Grande do Sul and is principally characterized by inflorescences (23-)30-39 cm long, with divergent basal racemes (figure 15). A short inflorescence, $12 \mathrm{~cm}$ long, was only observed in one specimen, together with a $37 \mathrm{~cm}$ long inflorescence.

Material selected: BRAZIL. Rio GRANDE Do SuL: Feliz, 19-VI-1971, ML Lorscheitter \& LRM Baptista s.n. (ICN 33395); Maquiné, Estação Experimental, 22-IV1974, O Rückiem s.n. (ICN 25599); Osório, road from Morro Alto to Capão da Canoa, 24-IV-1974, JFM Valls et al. 3291 (ICN); Rio Grande, Estação Ecológica do Taim, 10-VII-1986, JA Jarenkow 381 (PACA, PEL); Rolante to Boa Esperança, 22-IV-1967, L Arzivenco s.n. (BLA 11994); Taquara, RS-020, near km 80, 30-IV-1974, A Normann et al. 475 (BLA); Torres, between Vila São João and Praia Grande, 29-XII-1970, JFM Valls \& L Arzivenco 1384 (ICN).

2.3. Imperata tenuis Hack., Monogr. Phan. 6: 689. 1889.

Figures 17-18

Plants (67-)85-145 cm high. Leaf sheaths glabrous; blades (18-)21-88 cm $\times 3-5.5(-7) \mathrm{mm}$, glabrous on abaxial surface, glabrous or sparsely to subdensely pilose on adaxial surface, generally with trichomes $1.5-6 \mathrm{~mm}$ long at the base of adaxial surface, mainly on margins; ligule membranous-ciliate, 1-2.5 mm long.
Inflorescence contracted, (10-)15-26 cm long, basal racemes 1.5-4.5(-5.5) cm long, adpressed. Spikelets 3$5 \mathrm{~mm}$ long; glumes with long silky trichomes. Stamen 1. Caryopsis $0.7-1 \mathrm{~mm}$ long.

Ecuador to Argentina and Brazil (Filgueiras 2003b). Rio Grande do Sul: Campanha and Depressão Central, less common in Planalto Médio, Campos de Cima da Serra and Encosta do Sudeste, in wet grasslands, marshlands, and roadsides. Collected with flowers and fruits mainly from November to February.

Imperata tenuis is similar to I. brasiliensis, being distinguished mainly by having longer inflorescences, taller plants, and different habits (see comments under the latter species).

Material selected: BRAZIL. Rio Grande do Sul: Cambará do Sul, near Posto Fiscal de Itaimbezinho, 28-II-2010, CAD Welker 297 (ICN); Cacequi, 27-VI2009, AA Schneider 1642 (ICN); Novo Cabrais, BR287, 26-XI-2007, $R$ Trevisan 889 (ICN); Passo Fundo, Fazenda da Brigada Militar, 19-XII-1945, JR Swallen 7772 (PEL); Pelotas, Instituto Agronômico do Sul, 6XI-1945, JR Swallen \& FF Rocha 7289 (PEL); Portão to São Leopoldo, 27-XI-1935, C Orth S.n. (PACA 2708); Quaraí, road to Cati, 20-XI-1973, JFM Valls \& A Barcellos 2982 (ICN); Rosário do Sul to Cacequi, RS-640, 24-XI-2008, R Lerina \& GH Silveira 95 (ICN); Santana do Livramento, BR-158, 18-XII-2009, CAD Welker 241 (ICN); São Gabriel, BR-290, near km 451, 15-XII-2009, CAD Welker 219 (ICN); São Leopoldo, 15-XI-1903, J Dutra 638 (ICN); São Pedro do Sul, BR287, 26-XI-2007, R Trevisan 891 (ICN); Tupanciretã, 10-I-1938, AA Araújo 341 (BLA).

\section{Saccharum L., Sp. P1. 1: 54. 1753.}

Perennial, caespitose with short, thick rhizomes; nodes glabrous, glabrescent or pilose. Leaf blades linear, linear-lanceolate or lanceolate; ligule membranousciliate. Inflorescence a contracted or open panicle, bearing numerous alternate racemes on a central axis. Racemes differentiated into nodes and internodes, disarticulating at the nodes, densely to subdensely pilose, trichomes white, cream, or pink. Spikelets paired at each node of the rachis, one sessile and one pedicelled, homogamous, the pedicelled spikelet falling off first at maturity, the sessile falling off together with a rachis internode and the pedicel. Spikelets with 2 anthecia; 2 glumes chartaceous, the lower one two-keeled, the upper one one-keeled, anthecia hyaline. Sessile spikelet awnless or awned, with bisexual flower; lower anthecium neuter, lemma present, awnless, rarely shortly awned, 

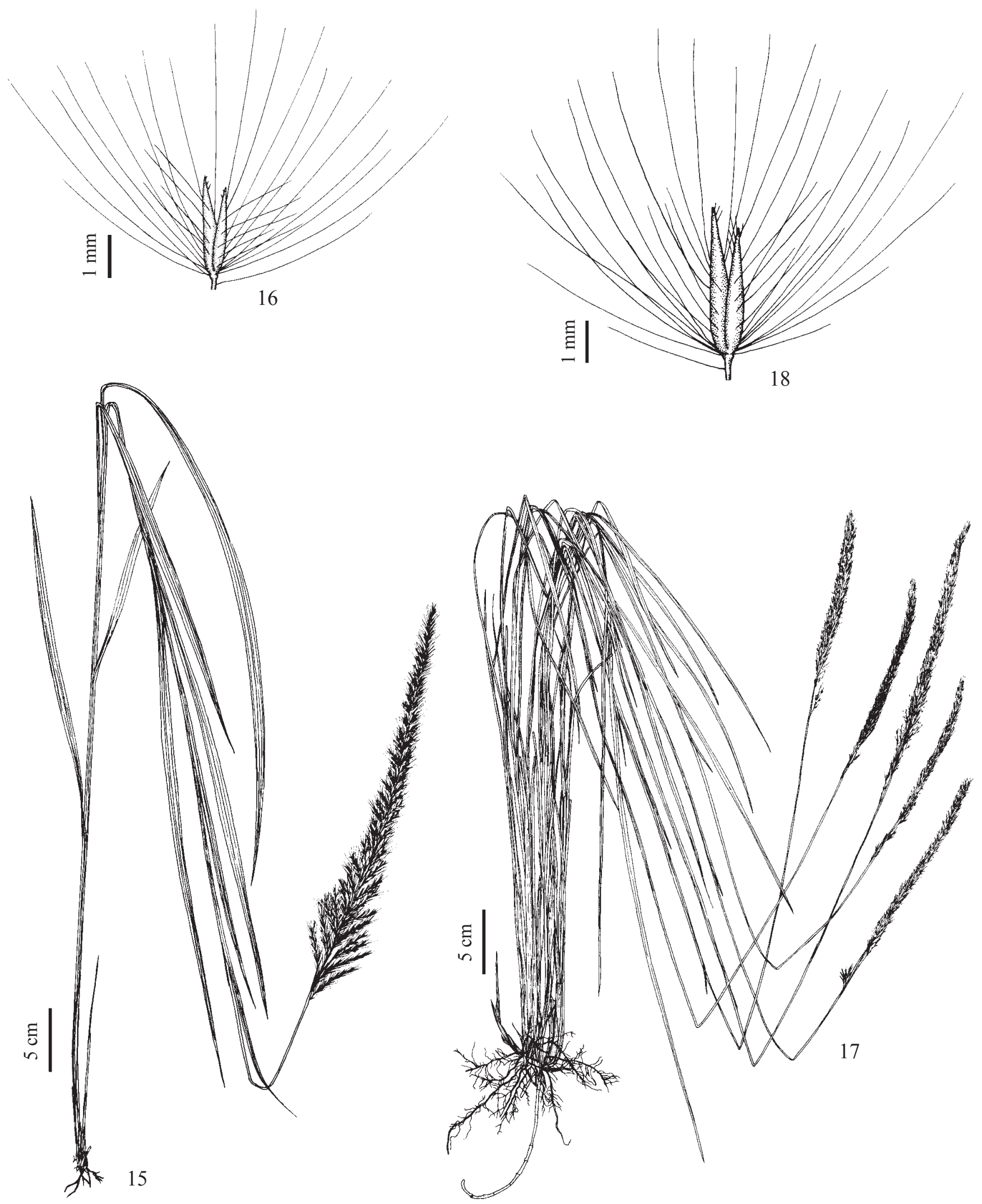

Figures 15-18. 15-16. Imperata contracta (Valls et al. 3291). 15. Habit. 16. Spikelet. 17-18. Imperata tenuis (Welker 241). 17. Habit. 18. Spikelet. 
palea lacking; upper anthecium with bisexual flower, lemma present, awnless or awned, palea rudimentary or lacking. Pedicelled spikelet awnless or awned, similar to the sessile, with bisexual flower. Stamens 2-3.

The genus Saccharum, in a broad sense, as accepted in this work, includes about 35-40 species distributed in tropical and subtropical regions of the world (Clayton \& Renvoize 1986). It is represented by three native species and one cultivated species (S. officinarum) in Rio Grande do Sul. The genus can be recognized in the field, even in its vegetative stage, by scabrous to strongly scabrous blade margins, with midrib conspicuously whitish.

Key to the species of Saccharum in Rio Grande do Sul

1. Lower glumes of the sessile and pedicelled spikelets glabrous, scabrous towards the apex 3.2. S. asperum

1. Lower glumes of the sessile and pedicelled spikelets densely to sparsely pilose, at least near the margins, sometimes the lower glume of the sessile spikelets glabrous in the same inflorescence.

2. Leaf blades linear, glabrous, 2-6 mm wide. Nodes glabrous, less commonly glabrescent

2. Leaf blades lanceolate, villous to sparsely pilose on one or both surfaces, less commonly glabrous, 7-20 mm wide; sometimes blades linear-lanceolate, 3-6 mm wide, on the same plant. Nodes pilose, less commonly glabrescent 3.3. S. villosum

In addition to these native species, Saccharum officinarum (sugar cane) is widely cultivated in Rio Grande do Sul. It is distinguished by its awnless spikelets, while the other species have awned spikelets. Additionally, the culms of $S$. officinarum are $2-5 \mathrm{~cm}$ in diameter, thicker than those of the native species (which can be up to $1.5 \mathrm{~cm}$ in diameter).

Overbeck et al. (2006) cited Saccharum alopecuroides (L.) Nutt. for Morro Santana, in Porto Alegre, Rio Grande do Sul, without citing the material examined. However, as was pointed out by Welker \& Longhi-Wagner (2007), this citation is probably mistaken, because $S$. alopecuroides only occurs in North America (Mukherjee 1958, Webster \& Shaw 1995, Filgueiras 2003c).

Several authors (e.g. Swallen 1966 and Smith et al. 1982, under Erianthus, Renvoize 1988 and Renvoize et al. 1998) used the character inflorescence exserted versus inflorescence partially included within the spathe in identification keys to separate the species of Saccharum. Field observations of different populations revealed that the three species occurring in Rio Grande do Sul may have inflorescences exserted or included within the spathe - so this is not a good taxonomic character. The development of exserted inflorescences in S. angustifolium (Nees) Trin. seems to be related to flowering after the fields have been burnt, as all of the plants observed with exserted inflorescences (an uncommon feature in this species) had burned culms at their bases. On the other hand, this relationship with fire is not evident in $S$. asperum (Nees) Steud. and $S$. villosum Steud., which usually form large populations of plants with exserted inflorescences that are not associated with burning.

3.1. Saccharum angustifolium (Nees) Trin., Mém. Acad. Imp. Sci. St.-Petersbourg, Ser. 6, Sci. Math., Seconde Pt. Sci. Nat. 4,2(1): 92.1836.

Erianthus angustifolius Nees, Agrostologia brasiliensis, in Mart., Fl. Bras. Enum. P1. 2: 316. 1829.

Figures 19-22

Plants (65-)95-225 cm high; nodes glabrous, less commonly glabrescent. Leaf sheaths glabrous or pubescent; blades linear, $22-106 \mathrm{~cm} \times 2-6 \mathrm{~mm}$, sometimes slightly narrowed to base, glabrous on both surfaces, strongly scabrous on margins; ligule 3.5$7.5(-11) \mathrm{mm}$ long. Inflorescence 13-38(-46) cm long, included within the spathe, less commonly exserted. Sessile spikelet (4.7-)5.5-7.3 mm long; lower glumes densely to sparsely pilose, at least near their margins, less commonly glabrous in the same inflorescence; upper glume densely to sparsely pilose or glabrous; upper lemma awned, awn 7.5-15 mm long. Pedicelled spikelet (4.5-)5.5-7.2 mm long; lower glumes densely to sparsely pilose, at least near their margins; upper glume densely to sparsely pilose, less commonly glabrous in the same inflorescence; upper lemma awned, awn 7-14 mm long. Caryopsis 2.4-3.5 mm long.

Venezuela, Colombia, Bolivia, Paraguay, Argentina, Uruguay, and Brazil (Molina 1981, Filgueiras 2003c). Brazil: Rio de Janeiro to Rio Grande do Sul (Smith et al. 1982). Rio Grande do Sul: throughout most of the state, in dry fields, rarely in wet fields. Collected with flowers and fruits mainly from October to April. 

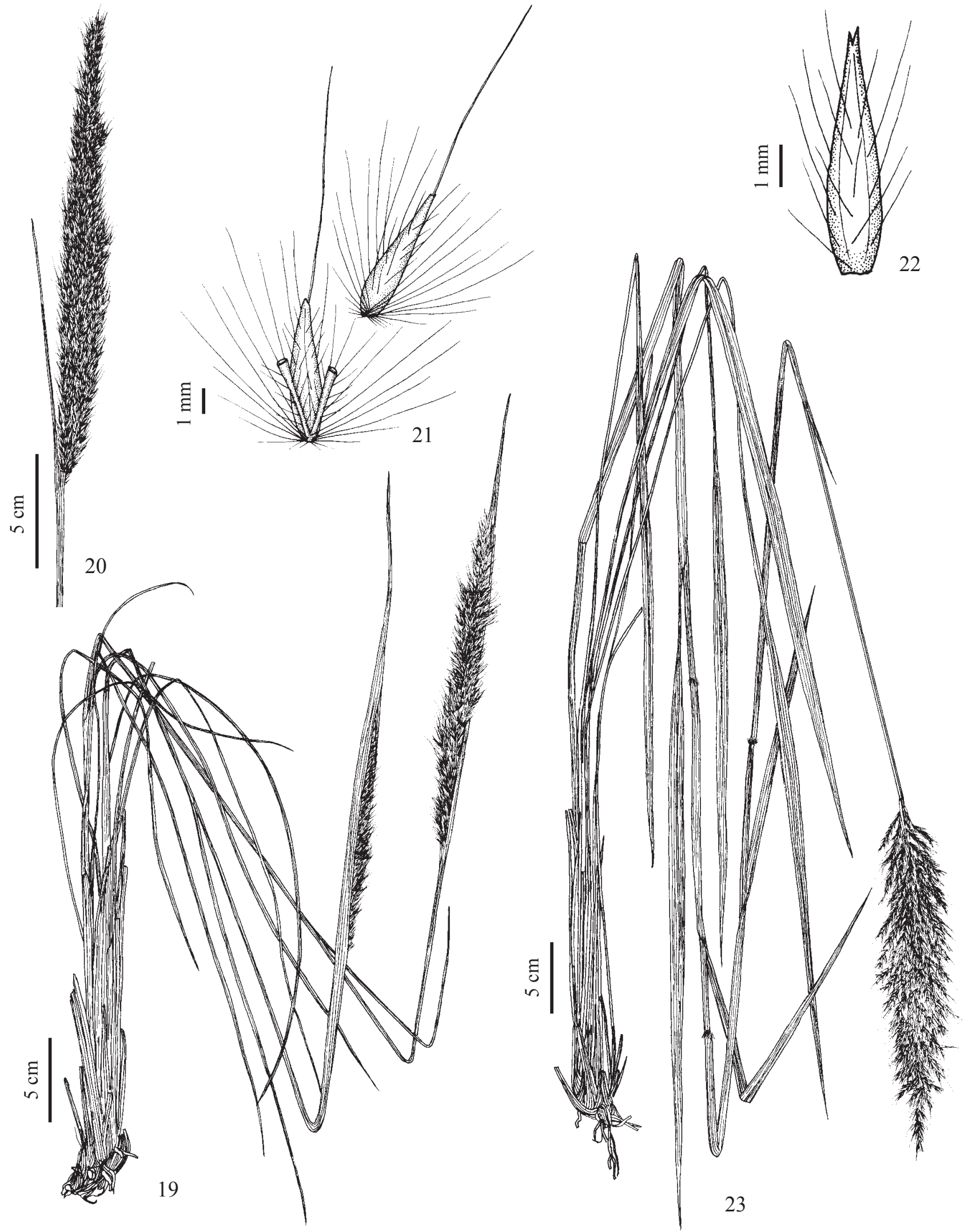

Figures 19-23. 19-22. Saccharum angustifolium. 19. Habit (Longhi-Wagner \& Welker 9781). 20. Inflorescence (Welker 260). 21. Pair of spikelets, pedicel, and rachis internode. 22. Lower glume of the sessile spikelet (Longhi-Wagner \& Welker 9781). 23. Saccharum asperum (Longhi-Wagner \& Welker 10811). Habit. 
Saccharum angustifolium is the most common species of this genus in Rio Grande do Sul. Its spikelets have lower glumes pilose, sometimes some sessile spikelets with lower glume glabrous in the same inflorescence, as in $S$. villosum. These species can be distinguished mainly by the shapes and widths of their leaf blades, linear and 2-6 mm wide in Saccharum angustifolium, but lanceolate and 7$20 \mathrm{~mm}$ wide (figure 27) in S. villosum (sometimes with blades linear-lanceolate, 3-6 mm wide, on the same plant). Moreover, the leafblades of S. angustifolium have a whitish midrib conspicuous until near the blade apex, midrib wider or almost as wide as the lateral portion of the blade. In $S$. villosum, the whitish midrib is generally narrower than the lateral portion of the blade and inconspicuous in the upper portion of the blade (see comments under $S$. villosum). The habitats of both species can also aid in distinguishing them: S. angustifolium occurs mainly in dry grasslands, whereas $S$. villosum exclusively inhabits marshlands and wet grasslands.

Mukherjee(1958)accepted Saccharumangustifolium (Nees) Trin. in the synonymy of Erianthus saccharoides Michx., a species described as having pilose leaf blades and trichomes at the base of the spikelets that are shorter than those spikelets. This description does not match the material of $S$. angustifolium from Rio Grande do Sul, which has glabrous blades and basal trichomes longer than the spikelets (figure 21). On the other hand, Filgueiras (2003c) accepted S. angustifolium and considered Erianthus saccharoides Michx. a superfluous illegitimate name, including it in the synonymy of Saccharum giganteum (Walter) Pers.

Material selected: BRAZIL. Rio Grande do Sul: Aceguá, BR-153, 6-I-2009, CAD Welker 188 (ICN); Bagé, 29-XII-1980, JC Lindeman 6884 (CNPO); Caçapava do Sul, RS-357, 8-X-2008, HM LonghiWagner \& CAD Welker 10571 (ICN); Cachoeira do Sul, BR-403, 7-X-2008, HM Longhi-Wagner \& CAD Welker 10561 (ICN); Cambará do Sul, RS-020, near km 156, 28-II-2010, CAD Welker 294 (ICN); Candiota, 20-X1987, P Oliveira et al. s.n. (CNPO 1533); Canela to São Francisco de Paula, 30-III-2009, HM Longhi-Wagner \& CAD Welker 10777 (ICN); Canguçu, BR-392, near km 145, 11-I-2010, CAD Welker 260 (ICN); Capão do Leão, Campus UFPEL, 11-IV-1994, EN Garcia 106 (PEL); Caxias do Sul, 19-III-2000, A Kegler 865 (HUCS); Eldorado do Sul, BR-290, 7-X-2008, HM LonghiWagner \& CAD Welker 10527 (ICN); Encruzilhada do Sul, road to Amaral Ferrador, 9-X-2008, HM LonghiWagner \& CAD Welker 10604 (ICN); Erechim, BR153, 27-XI-2008, $R$ Lerina \& GH Silveira 99 (ICN); Farroupilha, Parque dos Pinheiros, 30-V-1978, O Bueno
729 (HAS); Getúlio Vargas, Fazenda do Pomar, V-1916, AA Araújo s.n. (BLA 5473); Guaíba, road to Uruguaiana, near km 49, 2-IV-1971, JFM Valls 1480 (ICN); Hulha Negra, Estação Experimental Fitotécnica, 23-IX-1976, AM Girardi-Deiro 412 (CNPO); Jaquirana to Passo do S, 13-I-2009, HM Longhi-Wagner \& CAD Welker 10656 (ICN); Passo Fundo, 11-XII-1945, JR Swallen 7768 (PEL); Pelotas, 6-V-1959, JC Sacco 1145 (PEL); Piratini, 8-X-2008, HM Longhi-Wagner \& CAD Welker 10582 (ICN); Porto Alegre, Morro Santana, 28-IV-2005, HM Longhi-Wagner \& CAD Welker 9781 (ICN); Rio Grande, BR-471, 11-XI-2008, CAD Welker 169 (ICN); Rio Pardo to Cachoeira do Sul, RS-403, 7-X-2008, HM LonghiWagner \& CAD Welker 10548 (ICN); Rosário do Sul, RS-640, 24-XI-2008, R Lerina \& GH Silveira 94 (ICN); Santa Maria, Estação Experimental de Silvicultura, 8-IV1956, OR Camargo 589 (PACA); Santana da Boa Vista, road to Minas do Camaquã, 12-I-2010, CAD Welker 269 (ICN); Santiago, BR-453, near km 158, 24-IV-1979, JFM Valls et al. 4619 (ICN); São Borja to Itaqui, BR472, near km 449, 25-XI-2008, R Lerina \& GH Silveira 97 (ICN); São Francisco de Paula, RS-020, 13-I-2009, HM Longhi-Wagner \& CAD Welker 10626 (ICN); São Gabriel, Granja São José, 22-XII-1978, JFM Valls et al. 4342 (ICN); São Marcos, BR-116, near km 149, 1-XI1979, AIC Pereira 102 (ICN); Uruguaiana, BR-472, near km 548, 16-XII-2009, CAD Welker 232 (ICN); Vacaria, BR-116, near km 14, 5-III-2010, CAD Welker 317 (ICN); Viamão, Bairro Tarumã, near Lago Tarumã, 24-IV-2010, PJS Silva Filho 315 (ICN).

3.2. Saccharum asperum (Nees) Steud., Syn. Pl. Glumac. 1: 407.1854.

Erianthus asper Nees, Agrostologia brasiliensis, in Mart., Fl. Bras. Enum. Pl. 1: 315. 1829.

Erianthus asper Nees var. brasilianus (Trin.) Hack., in Mart., Fl. Bras. 2(4): 259. 1883 (cited for Rio Grande do Sul by Molina 1981).

Figures 23-25

Plants 102-265 cm high; nodes pilose or glabrescent. Leaf sheaths glabrous or pubescent; blades lanceolate, $22-102 \mathrm{~cm} \times 7-23 \mathrm{~mm}$, narrowed to base, glabrous on abaxial surface, glabrous, sparsely pilose or villous on adaxial surface, scabrous on margins; ligule 2.5$6 \mathrm{~mm}$ long. Inflorescence 14-43 cm long, exserted, less commonly included within the spathe. Sessile spikelet 4-6.5 mm long; lower and upper glumes glabrous, scabrous towards the apex; upper lemma awned, awn 5-12 mm long. Pedicelled spikelet 4-6.5 mm long; lower and upper glumes glabrous, scabrous towards the apex; 
upper lemma awned, awn 5-11 mm long. Caryopsis 2.3$2.7 \mathrm{~mm}$ long.

Venezuela, Colombia, Paraguay, Argentina, Uruguay and Brazil (Molina 1981, Filgueiras 2003c). Brazil: Goiás to Rio Grande do Sul (Smith et al. 1982). Rio Grande do Sul: Campos de Cima da Serra, less common in Planalto Médio, Encosta Superior do Nordeste, Encosta Inferior do Nordeste, Depressão Central and Litoral, in marshlands, less commonly in wet grasslands. Collected with flowers and fruits from December to March.

Among the characteristics used by Molina (1981) to separate Saccharum asperum (under Erianthus asper) from the other species of the genus are the fertile lemma non-bidentatec and both spikelets pedicelled, one of them with a very short pedicel (about $1 \mathrm{~mm}$ long). However, these characteristics can also be found in other species of this genus. On the other hand, the absence of trichomes on the lower glume of the spikelets, also used by Molina (1981), appears to be the best feature separating this species from the others occurring in Rio Grande do Sul.

Material selected: BRAZIL. Rio GRANDE Do SUL: Bom Jesus, RS-110, 14-I-2009, HM Longhi-Wagner \& CAD Welker 10673 (ICN); Cambará do Sul, RS-020, near km 156, 28-II-2010, CAD Welker 295 (ICN); Canela, Sítio Felix Garcez, 30-III-2009, HM Longhi-Wagner \& CAD Welker 10766 (ICN); Caxias do Sul, 8-II-1955, B Rambo 56787 (PACA); Maquiné, 10-II-2002, GC Souza s.n. (ICN 126782); Passo Fundo, Fazenda da Brigada Militar, 19-XII1945, JR Swallen 7780 (PEL); Riozinho, 15-III-1997, L Palma s.n. (PACA 95481); São Francisco de Paula, Colinas de São Francisco, 31-III-2009, HM Longhi-Wagner \& CAD Welker 10811 (ICN); São Leopoldo, 4-III-1933, C Orth s.n (PACA 1052); Torres, 30-I-1964, IL Barreto \& A Kappel s.n. (BLA 3934); Vacaria, BR-116, near km 14, 5-III-2010, CAD Welker 315 (ICN).

3.3. Saccharum villosum Steud., Syn. P1. Glumac. 1: 408. 1854.

Erianthus clandestinus Swallen, Phytologia 14(2): 93. 1966 (cited for Rio Grande do Sul by Swallen 1966). Erianthus glabrinodis (Hack.) Swallen, Phytologia 14(2): 93. 1966 (cited for Rio Grande do Sul by Swallen 1966). Erianthus trinii (Hack.) Hack., Monogr. Phan. 6: 135. 1889 (cited for Rio Grande do Sul by Molina 1981). Figures 26-30

Plants (70-)115-310 cm high; nodes pilose, less commonly glabrescent. Leaf sheaths hirsute or pubescent, less commonly glabrous; blades lanceolate, $30-115 \mathrm{~cm} \times 7$ $20 \mathrm{~mm}$, sometimes with blades linear-lanceolate, 35-105 $\times$
3-6 mm on the same plant, both narrowed to base, villous to sparsely pilose on one or both surfaces, less commonly glabrous on both surfaces, scabrous on margins; ligule 2.5-8 mm long. Inflorescence 20-48 cm long, exserted, less commonly included within the spathe. Sessile spikelet 5-7 mm long; lower glume densely to sparsely pilose, at least near their margins, rarely glabrous in the same inflorescence; upper glume densely to sparsely pilose, less commonly glabrous in the same inflorescence; upper lemma awned, awn 5-14 mm long. Pedicelled spikelet 5-7.5 mm long; lower and upper glumes densely to sparsely pilose, at least near their margins; upper lemma awned, awn 6.5-13 mm long. Caryopsis 2.2-3 mm long.

Mexico to Argentina and Brazil (Molina 1981, Filgueiras 2003c). Brazil: Minas Gerais to Rio Grande do Sul (Filgueiras \& Lerina 2001b). Rio Grande do Sul: throughout most of the state, in marshlands and wet grasslands. Collected with flowers and fruits mainly from October to March.

Erianthus clandestinus, E. glabrinodis, and E. trinii, cited for Rio Grande do Sul by different authors (Swallen 1966, Araújo 1971, Molina 1981, Smith et al. 1982, Rambo 1984), are considered synonyms of Saccharum villosum (Filgueiras \& Lerina 2001b, Filgueiras 2003c and Morrone et al. 2008). Great variability was observed in the material collected in Rio Grande do Sul and identified as Saccharum villosum, mainly in relation to the sizes and indumentum of the leaves, with a predominance of specimens been densely pilose to villous with small numbers of glabrous plants. It is possible that more than one species is involved, which will require additional study.

Most of the material of Saccharum villosum and S. angustifolium collected in Rio Grande do Sul can be differentiated by leaf characteristics (see comments under the latter species). Some specimens, however, have leaf blades with midribs and indumentum typical of $S$. villosum, but narrower than usual for the species, with widths similar to that of $S$. angustifolium. These specimens are listed below as Saccharum aff. villosum Steud. According to Hodkinson et al. (2002), the taxonomy of Saccharum is very complex, and interspecific and intergeneric hybrids make the situation even more complicated. It is possible that specimens with intermediate leaf morphologies are natural hybrids between $S$. villosum and $S$. angustifolium.

Due to controversial circunscriptions, the variability observed in the Saccharum villosum complex, as well as the possibility of occurrence of hybrids, we are currently conducting molecular and cytogenetic analysis to better define these taxa. 

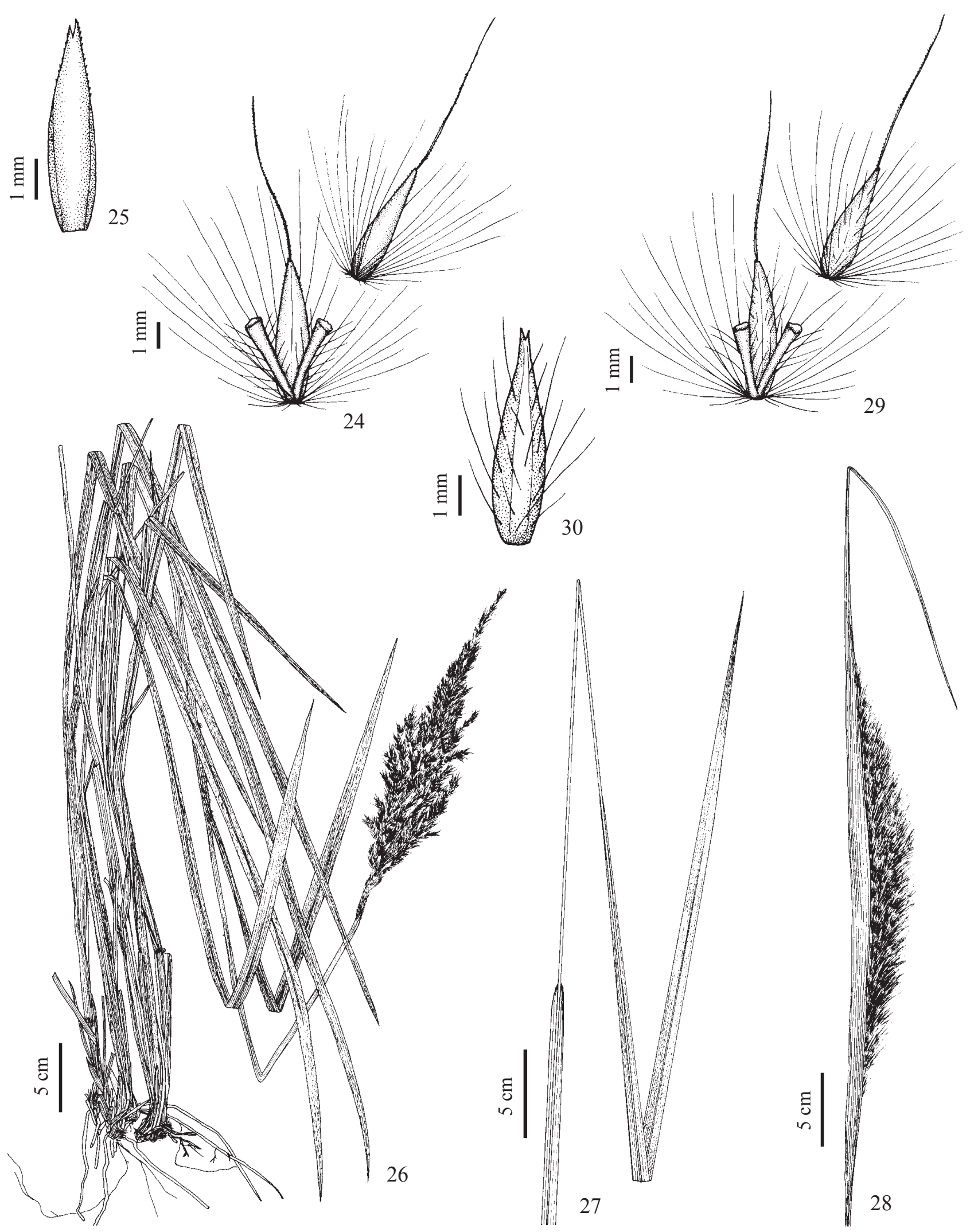

Figures 24-30. 24-25. Saccharum asperum (Longhi-Wagner \& Welker 10811). 24. Pair of spikelets, pedicel, and rachis internode. 25. Lower glume of the sessile spikelet. 26-30. Saccharum villosum. 26. Habit (Longhi-Wagner \& Welker 10665). 27. Leaf sheath and blade (Longhi-Wagner \& Welker 10611). 28. Inflorescence (Longhi-Wagner \& Welker 10805a). 29. Pair of spikelets, pedicel, and rachis internode. 30. Lower glume of the sessile spikelet (Longhi-Wagner \& Welker 10665). 
Material selected: BRAZIL. Rio Grande Do Sul: Alegrete, BR-290, near km 532, 15-XII-2009, CAD Welker 222 (ICN); Arroio do Meio, 11-IV-1955, IL Barreto s.n. (BLA 1650); Caçapava do Sul, RS-357, 8-X-2008, HM Longhi-Wagner \& CAD Welker 10570 (ICN); Cambará do Sul, RS-020, 16-I-2009, HM LonghiWagner \& CAD Welker 10750 (ICN); Canela, Sítio Felix Garcez, 30-III-2009, HM Longhi-Wagner \& CAD Welker 10763 (ICN); Capivari do Sul, RS-040, 3-X-2008, HM Longhi-Wagner \& CAD Welker 10521 (ICN); Caxias do Sul, Vila Seca, 19-II-2000, A Kegler 732 (HUCS); Ciríaco, BR-285, near km 120, 23-VII-1973, JFM Valls et al. 2676 (ICN); Dois Irmãos, 3-VII-1935, C Orth s.n. (PACA 2737); Eldorado do Sul, BR-290, 7-X2008, HM Longhi-Wagner \& CAD Welker 10524 (ICN); Encruzilhada do Sul, road to Amaral Ferrador, 9-X2008, HM Longhi-Wagner \& CAD Welker 10611 (ICN); Getúlio Vargas, Fazenda do Pomar, V-1916, AA Araújo s.n. (BLA 5547); Jaquirana, 13-I-2009, HM LonghiWagner \& CAD Welker 10665 (ICN); Nova Petrópolis to Gramado, 30-III-1999, HM Longhi-Wagner 6080 (ICN); Porto Alegre, Morro Santana, 8-III-2005, CAD Welker 87 (ICN); Pouso Novo to Marques de Souza, 13-II-2009, GH Silveira 802 (ICN); Quaraí, BR-293, 7-I-2009, CAD Welker 197 (ICN); Riozinho, road to Sampaio Ribeiro, Morro da Canastra, 3-XII-2008, $R$ Lerina \& GH Silveira 102 (ICN); Santa Maria, Estação Experimental de Silvicultura, 3-II-1956, OR Camargo 163 (PACA); Santo Cristo to Porto Lucena, RS-472, near km 158, 23-III-2010, CAD Welker 322 (ICN); São Borja, BR-287, near km 460, 16-XII-2009, CAD Welker 229 (ICN); São Francisco de Assis to São Vicente do Sul, RS241, near km 52, 9-I-2009, CAD Welker 214 (ICN); São Francisco de Paula, 31-III-2009, HM Longhi-Wagner \& CAD Welker 10805a (ICN); São José dos Ausentes, RS-020, 2-III-2010, CAD Welker 304 (ICN); São Luiz Gonzaga to Santo Antônio das Missões, BR-285, near km 577, 24-III-2010, CAD Welker 327 (ICN); Sarandi, Parque Florestal Estadual Rondinha, 27-XI-2008, $R$ Lerina \& GH Silveira 98 (ICN); Taquara, RS-020, near $\mathrm{km}$ 76, 15-XI-1973, JFM Valls et al. 2864 (ICN); Terra de Areia, 18-III-2008, $R$ Trevisan 954 (ICN); Vacaria, BR-116, near km 14, 5-III-2010, CAD Welker 318 (ICN); Xangri-lá, 22-XII-2009, CAD Welker 252 (ICN).

Saccharum aff. villosum Steud.: BRAZIL. Rio GRANDE DO Sul: Jaquirana, RS-010, 13-I-2009, HM Longhi-Wagner \& CAD Welker 10650 (ICN); Lavras do Sul to Bagé, RS-473, 13-I-2010, CAD Welker 276 (ICN); Passo Fundo, Granja Antônio Amantino, 16-X-1982, B Severo et al. s.n. (RSPF 1973); Porto Alegre, Morro São Pedro, Econsciência Espaço de Conservação, 19-V-
2005, R Setubal \& M Grings 377 (ICN); Quaraí, BR-293, near km 439, 17-XII-2009, CAD Welker 238 (ICN); São Borja to Santiago, BR-287, 21-XII-2010, HM LonghiWagner \& CAD Welker 10839 (ICN); São Leopoldo, 20-VII-1934, C Orth s.n (PACA 1008); Vacaria, Estação Experimental de Forrageiras, 21-III-1962, VR Froner s.n. (BLA 3010).

Acknowledgements - We are grateful to the curators of the herbaria cited for loans of the specimens, and to the Brazilian Research Council (Conselho Nacional de Desenvolvimento Científico e Tecnológico - CNPq) for grants and fellowships.

\section{REFERENCES}

Araújo AA. 1971. Principais gramíneas do Rio Grande do Sul. Sulina, Porto Alegre.

Beauvois AMFJP. 1812. Essai d'une nouvelle Agrostographie; ou nouveaux genres des Graminées; avec figures représentant les caractères de tous les genres. Chez l'auteur, Paris.

Besse P, Mcintyre CL, Berding N. 1997. Characterization of Erianthus sect. Ripidium and Saccharum germplasm (Andropogoneae - Saccharinae) using RFLP markers. Euphytica 93:283-292.

Burkart A, Toursarkissian M. 1969. Tribu Andropogoneae. In Flora Ilustrada de Entre Ríos (Argentina). Parte II: Gramíneas (A Burkart, JA Caro, KA Okada, RA Palacios, ZE Rúgolo de Agrasar, E Sánchez de García, M Toursarkissian, NST Burkart, eds.). Instituto Nacional de Tecnologia Agropecuária, Buenos Aires, p.447-508.

Clayton WD, Renvoize SA. 1986. Genera graminum: grasses of the world. Her Majesty's Stationery Office, London.

Filgueiras TS. 2003a. Eriochrysis P. Beauv. In Catalogue of New World Grasses (Poaceae): III. Subfamilies Panicoideae, Aristidoideae, Arundinoideae and Danthonioideae (FO Zuloaga, O Morrone, G Davidse, TS Filgueiras, PM Peterson, RJ Soreng, EJ Judziewicz, eds.). Contributions from the United States National Herbarium 46:239-240.

Filgueiras TS. 2003b. Imperata Cirillo. In Catalogue of New World Grasses (Poaceae): III. Subfamilies Panicoideae, Aristidoideae, Arundinoideae and Danthonioideae (FO Zuloaga, O Morrone, G Davidse, TS Filgueiras, PM Peterson, RJ Soreng, EJ Judziewicz, eds.). Contributions from the United States National Herbarium 46: 270-273.

Filgueiras TS. 2003c. Saccharum L. In Catalogue of New World Grasses (Poaceae): III. Subfamilies Panicoideae, Aristidoideae, Arundinoideae and Danthonioideae (FO Zuloaga, O Morrone, G Davidse, TS Filgueiras, PM Peterson, RJ Soreng, EJ Judziewicz, eds.). Contributions from the United States National Herbarium 46: 550-557. 
Filgueiras TS. 2010a. Eriochrysis P. Beauv. In Catálogo de Plantas e Fungos do Brasil (RC Forzza et al., orgs.). v.2. Instituto de Pesquisas Jardim Botânico do Rio de Janeiro, Rio de Janeiro, p.1484.

Filgueiras TS. 2010b. Imperata Cirillo. In Catálogo de Plantas e Fungos do Brasil (RC Forzza et al., orgs.). v.2. Instituto de Pesquisas Jardim Botânico do Rio de Janeiro, Rio de Janeiro, p.1489.

Filgueiras TS. 2010c. Saccharum L. In Catálogo de Plantas e Fungos do Brasil (RC Forzza et al., orgs.). v.2. Instituto de Pesquisas Jardim Botânico do Rio de Janeiro, Rio de Janeiro, p.1512.

Filgueiras TS, Lerina R. 2001a. Eriochrysis P. Beauv. In Flora Fanerogâmica do Estado de São Paulo. Poaceae (HM Longhi-Wagner, V Bittrich, MGL Wanderley, GJ Shepherd, eds.). Hucitec, São Paulo, p.101-102.

Filgueiras TS, Lerina R. 2001b. Saccharum L. In Flora Fanerogâmica do Estado de São Paulo. Poaceae (HM Longhi-Wagner, V Bittrich, MGL Wanderley, GJ Shepherd, eds.). Hucitec, São Paulo, p.108-110.

Flores AIP. 2001. Imperata Cirillo. In Flora Fanerogâmica do Estado de São Paulo. Poaceae (HM Longhi-Wagner, V Bittrich, MGL Wanderley, GJ Shepherd, eds.). Hucitec, São Paulo, p.105-106.

Fortes AB. 1959. Geografia física do Rio Grande do Sul. Globo, Porto Alegre.

Gabel ML. 1982. A biosystematic study of the genus Imperata (Gramineae: Andropogoneae). PhD thesis, Iowa State University, Ames.

Hodkinson TR, Chase MW, Lledó MD, Salamin N, Renvoize SA. 2002. Phylogenetics of Miscanthus, Saccharum and related genera (Saccharinae, Andropogoneae, Poaceae) based on DNA sequences from ITS nuclear ribosomal DNA and plastid trnL intron and trnL-F intergenic spacers. Journal of Plant Research 115: 381-392.

Judziewicz EJ. 1990. Poaceae (Gramineae). In Flora of the Guianas. Series A: Phanerogams (ARA Görts-van Rijn, ed.). Koeltz Scientific Books, Koenigstein, p.1-727.

Molina AM. 1981. El género Erianthus (Gramineae) en la Argentina y países limítrofes. Darwiniana 23:559-585.

Morrone O, Zuloaga FO, Longhi-Wagner HM, Izaguirre P, Beyhaut R, Cialdella AM, Giussani L, Denham SS, Guglieri A, Boldrini I, Zanin A, Salariato D, de Gennaro D. 2008. Poaceae. In Catálogo de las Plantas Vasculares del Cono Sur (Argentina, Sur de Brasil, Chile, Paraguay y Uruguay). v.1. Pteridophyta, Gymnospermae y Monocotyledoneae (FO Zuloaga, O Morrone, MJ Belgrano, eds.). Missouri Botanical Garden Press, Missouri, p.609-967.
Mukherjee SK. 1958. Revision of the genus Erianthus Michx. (Gramineae). Lloydia 21:157-188.

Nair NV, Selvi A, Sreenivasan TV, Pushpalatha KN, Mary S. 2005. Molecular diversity among Saccharum, Erianthus, Sorghum, Zea and their hybrids. Sugar Tech 7:55-59.

Nicora EG, Rúgolo de Agrasar ZE. 1987. Los géneros de gramíneas de América Austral: Argentina, Chile, Uruguay y áreas limítrofes de Bolivia, Paraguay y Brasil. Editorial Hemisferio Sur, Buenos Aires.

Overbeck GE, Müller SC, Pillar VD, Pfadenhauer J. 2006. Floristic composition, environmental variation and species distribution patterns in burned grassland in southern Brazil. Brazilian Journal of Biology 66: 1073-1090.

Rambo B. 1984. Gramineae Riograndenses. Pesquisas 36: $1-191$.

RBH. 2011. Rede Brasileira de Herbários. Sociedade Botânica do Brasil. http://www.ufrgs.br/taxonomia/herbarios.asp (accessed 2011 Jun 20).

Renvoize SA. 1988. Hatschbach's Paraná grasses. Royal Botanic Gardens, Kew.

Renvoize SA, Anton A, Beck S. 1998. Gramíneas de Bolivia. Royal Botanic Gardens, Kew.

Sánchez-Ken JG, Clark LG. 2010. Phylogeny and a new tribal classification of the Panicoideae s.l. (Poaceae) based on plastid and nuclear sequence data and structural data. American Journal of Botany 97:1732-1748.

Selvi A, Nair NV, Noyer JL, Singh NK, Balasundaram N, Bansal KC, Koundal KR, Mohapatra T. 2006. AFLP analysis of the phenetic organization and genetic diversity in the sugarcane complex, Saccharum and Erianthus. Genetic Resources and Crop Evolution 53:831-842.

Smith LB, Wasshausen DC, Klein RM. 1982. Gramíneas. Gêneros: 85. Paspalum até 115. Zea. In Flora Ilustrada Catarinense (R. Reitz, ed.). Herbário Barbosa Rodrigues, Itajaí, p.909-1410.

Swallen JR. 1966. Notes on grasses. Phytologia 14:65-98.

Thiers B. 2011. Index Herbariorum: a global directory of public herbaria and associated staff. New York Botanical Garden's Virtual Herbarium. http://sweetgum.nybg.org/ ih/ (accessed 2011 Jun 20).

Watson L, Dallwitz MJ. 1992. The grass genera of the world. C.A.B. International, Wallingford.

Webster RD, Shaw RB. 1995. Taxonomy of the native North American species of Saccharum (Poaceae: Andropogoneae). Sida 16:551-580.

Welker CAD, Longhi-Wagner HM. 2007. A família Poaceae no Morro Santana, Rio Grande do Sul, Brasil. Revista Brasileira de Biociências 5:53-92. 
List of exsiccates

Allem, A: 1886 (3.1-ICN). Araújo, AA: 341 (2.3BLA), s.n. (2.1-BLA 1567), s.n. (3.1-BLA 5239), s.n. (3.1-BLA 5473), s.n. (3.3-BLA 5547). Arzivenco, L: s.n. (2.2-BLA 11994). Barbosa, E: 431 (3.2-HUCS). Barreto, IL: s.n. (3.1-BLA 712), s.n. (1.1-BLA 1012), s.n. (2.3-BLA 1277), s.n. (3.1-BLA 1409), s.n. (3.3-BLA 1650), s.n. (3.1-BLA 3686), s.n. (3.2-BLA 3934), s.n. (3.2-BLA 4032). Barros, F: 880 (1.1-ICN). Beetle, AA: 1852 (2.1-PACA). Bertels, A: 2111 (2.1-PEL). Boechat, SC: s.n. (3.2-ICN 41051), s.n. (1.2-ICN 41052), s.n. (2.1-ICN 101720), s.n. (3.3-ICN 101721), s.n. (1.2-ICN 101736). Boldrini, II: 1507 a (2.3-ICN), s.n. (2.3-BLA 7980). Bueno, O: 702 (3.1-HAS), 729 (3.1-HAS), 1006 (3.1-HAS), s.n. (1.1-ICN 92620). Camargo, OR: 30 (1.1-PACA), 163 (3.3-PACA), 589 (3.1-PACA), 1633 (3.1-PACA), 2499 (1.2-PACA), s.n. (1.1-BLA 2082). Campos, R: s.n. (1.2-ICN 68672). Carmo, MRB: 450 (1.3-ICN), 727 (1.1-ICN). Coelho, GC: s.n. (1.3-HUI 2087). Dutra, J: 463 (1.3-ICN), 470 (3.2-ICN), 611 (3.3ICN), 638 (2.3-ICN). Eggers, L: 22 (1.3-ICN), 88 (3.1ICN). Fagundes, V: s.n. (3.1-BLA 2405), s.n. (3.1-BLA 2406), s.n. (1.1-BLA 2416). Farias H: s.n. (3.1-RSPF 3862). Ferreira, HD: 372 (1.1-ICN). Filgueiras, TS: 1932 (1.1-ICN). Fittkau: s.n.: (1.1-INPA 12829). Froner, VR: s.n. (1.3-BLA 3014), s.n. (1.3-BLA 3015). Gameiro, AH: 116 (3.1-PEL). Garcia, EN: 106 (3.1-PEL), 111 (3.1-PEL). Girardi-Deiro, AM: 275 (3.1-CNPO), 412 (3.1-CNPO), 1334 (3.1-CNPO), 1415 (3.1-CNPO), 1446 (3.1-CNPO), 1525 (3.1-CNPO), s.n. (3.1-ICN 28593). Gonçalves, V: 91 (2.1-ICN), 106 (2.1-ICN). Hatschbach, G: 1441 (1.2-PACA). Henz, E: s.n. (1.1-PACA 36965). Heyde: 3564 (1.1-K). Irgang, BE: s.n. (2.1-ICN 27878). Jarenkow, JA: 273 (2.1-PEL), 381 (2.2-PACA, PEL). Kappel, A: s.n. (2.1-BLA 2559), s.n. (3.1-BLA 4090), s.n. (2.1-BLA 12028). Kegler, A: 626 (3.1-HUCS), 693 (1.1-HUCS), 732 (3.3-HUCS), 865 (3.1-HUCS), 876 (1.1-HUCS). Klein, RM: 9272 (1.1-PEL). Krieger, L: 23809 (1.1-ICN). Larocca, J: s.n. (3.1-PACA 100454). Leonhardt, A: s.n. (3.2-ICN 126434). Lerina, R: 94 (3.1ICN), 95 (2.3-ICN), 97 (3.1-ICN), 98 (3.3-ICN), 99 (3.1-ICN), 100 (2.1-ICN), 102 (3.3-ICN). Lindeman, JC: 6884 (3.1-CNPO). von Linsingen, L: 560 (1.3-ICN). Longhi-Wagner, HM: 997 (1.2-ICN), 1698 (3.1-ICN), 1705 (1.3-ICN), 1710 (1.1-ICN), 1802 (1.2-ICN), 1831 (1.2-ICN), 1928 (1.3-ICN), 2077 (1.3-ICN), 2091 (1.3ICN), 2142 (2.1-ICN), 2486 (1.3-ICN), 3315 (1.1-ICN), 3382 (1.1-ICN), 5089 (3.1-ICN), 6015 (3.2-ICN), 6023 (3.1-ICN), 6044 (3.3-ICN), 6045 (1.1-ICN), 6080 (3.3ICN), 6081 (3.3-ICN), 6082 (3.1-ICN), 6089 (1.1-ICN),
7192 (1.3-ICN), 8716 (3.3-ICN), 9100a (1.1-ICN), 9255 (1.2-ICN), 9411 (1.1-ICN), 9705 (3.1-ICN), 9781 (3.1 ICN), 9783 (3.1-ICN), 9790 (3.1-ICN), 9809 (3.1-ICN), 9910 (1.2-ICN), 9920 (1.3-ICN), 10169 (1.2-ICN), 10181 (1.2-ICN), 10521 (3.3-ICN), 10524 (3.3-ICN), 10527 (3.1-ICN), 10548 (3.1-ICN), 10549 (3.1-ICN), 10555 (3.1-ICN), 10556 (3.1-ICN), 10558 (1.1-ICN), 10561 (3.1-ICN), 10570 (3.3-ICN), 10571 (3.1-ICN), 10572 (3.1-ICN), 10582 (3.1-ICN), 10604 (3.1-ICN), 10611 (3.3-ICN), 10612 (1.1-ICN), 10617 (3.3-ICN), 10621 (3.2-ICN), 10626 (3.1-ICN), 10642 (1.1-ICN), 10655 (3.3-ICN), 10656 (3.1-ICN), 10662 (3.3-ICN), 10665 (3.3-ICN), 10670 (3.3-ICN), 10671 (3.3-ICN), 10673 (3.2-ICN), 10675 (1.1-ICN), 10683 (3.2-ICN), 10696 (3.2-ICN), 10701 (1.2-ICN), 10709 (1.2-ICN), 10726 (1.1-ICN), 10731 (1.2-ICN), 10735 (1.2-ICN), 10748 (3.3-ICN), 10749 (3.3-ICN), 10750 (3.3-ICN), 10763 (3.3-ICN), 10766 (3.2-ICN), 10767 (3.2-ICN), 10772 (1.1-ICN), 10777 (3.1-ICN), 10780 (1.1-ICN), 10781 (1.1-ICN), 10794 (1.1-ICN), 10797 (1.3-ICN), 10799 (3.2-ICN), 10800 (1.1-ICN), 10801 (3.2-ICN), 10803 (1.1-ICN), 10805a (3.3-ICN), 10805 b (3.2-ICN), 10811 (3.2-ICN), 10815 (2.1-ICN), 10822 (2.1-ICN), 10827 (3.3-ICN), 10833 (3.3-ICN), 10847 (1.3-ICN), 10848 (2.1-ICN), 10849 (1.3-ICN). Lorscheitter, ML: s.n. (2.2-ICN 33395), s.n. (3.1-ICN 33406). Marchett, F: 49 (2.1-HUCS). Martins, S: 320 (3.1-HAS). Mattos, J: 13380 (1.1-HAS), 25980 (3.2-HAS), 27201 (1.2HAS), 27226 (1.2-HAS), 29076 (3.1-HAS), 29115 (1.1HAS), 29618 (3.1-HAS). Matuda, E: 3750 (1.1-K). Mauhs, J: s.n. (1.3-ICN 146284, PACA 87025). Mohrdieck, KH: 36 (1.3-BLA). Mondin, C: 1997 (2.1PACA). Neves, PC: s.n. (1.1-ICN 83445). Normann, A: 147 (2.1-BLA), 475 (2.2-BLA), s.n. (2.1-BLA 8417). Oliveira, P: s.n. (3.1-CNPO 1533). Orth, C: s.n. (3.2PACA 1052), s.n. (1.1-PACA 1054), s.n. (2.3-PACA 2708), s.n. (3.3-PACA 2737). Palma, C: 28 (2.1-ICN). Palma, L: s.n. (3.2-PACA 95481). Pedersen, TM: 6007 (1.1-K), 8605 (1.1-K). Pereira, AIC: 102 (3.1-ICN). Pereira, E: 4208 (3.2-PEL). Pereira, J: s.n. (2.1-ICN 25587). Pietrobom-Silva, MR: 2703 (1.1-ICN), 2765 (1.1-ICN), 2875 (1.1-ICN), 2897 (1.1-ICN), 3114 (1.1ICN). Pilz, A: 286 (3.1-ICN), 312 (1.3-ICN). Pohl, RW: 12308 (1.1-K). Porto, ML: s.n. (1.3-ICN 9596), s.n. (3.1-ICN 25490). Pott, A: s.n. (1.1-BLA 9664). Rambo, B: 28475 (1.1-PACA), 35159 (1.3-PACA), 36461 (3.2PACA), 36476 (1.1 and 1.3-PACA), 41390 (3.1-PACA), 41573 (3.1-PACA), 45936 (3.2-PACA), 46488 (2.2PACA), 52049 (1.1-PACA), 52218 (3.2-PACA), 54105 (3.2-PACA), 54574 (1.2-PACA), 56787 (3.2-PACA), 56789 (1.3-PACA). Ramos, M: s.n. (2.3-PEL 5139). 
Reitz, R: s.n. (2.2-PACA 25457). Renvoize, S: 4601 (1.1-K). Rückiem, O: s.n. (2.2-ICN 25599). Rúgolo de Agrasar, ZE: 1766 (1.1-ICN). Sacco, JC: 313 (3.1-PEL), 550 (3.1-PEL), 1145 (3.1-PEL). Scherer, C: s.n. (1.2ICN 126394). Schneider, AA: 1642 (2.3-ICN). Schultz, A: 678 (3.2-ICN), 682 (3.1-ICN). Scur, L: 451 (1.1HUCS), 510 (1.1-HUCS), 543 (3.3-HUCS), 646 (3.1HUCS), 1016 (1.1-HUCS), 1137 (3.3-HUCS). Sehnem, A: s.n. (3.2-PACA 87491). Setubal, R: 248 (3.1-ICN), 250 (3.1-ICN), 667 (1.1-ICN), 716 (2.3-ICN). Silva, AP: s.n. (3.1-BLA 2512). Silva, ELS: 668 (1.1-INPA). Silva Filho, PJS: 315 (3.1-ICN), 316 (3.1-ICN). Silveira, GH: 553 (1.2-ICN), 802 (3.3-ICN). Simas, H: 35451 (2.1-PACA). Smith, LB: 13015 (1.2-ICN). Sobral, M: 6309 (1.1-ICN). Souza, GC: s.n. (3.2-ICN 126782). Souza, ML: 778 (1.1-HUCS). Swallen, JR: 7125 (2.1PEL), 7289 (2.3-PEL), 7307 (1.2-PEL), 7752 (1.1-PEL), 7768 (3.1-PEL), 7772 (2.3-PEL), 7776 (3.2-PEL), 7780 (3.2-PEL), 7781 (3.1-PEL), 8048 (3.1-PEL), 8086 (3.1PEL), 8144 (1.1-PEL), 8155 (3.2-PEL), 8199 (3.2-PEL), 8214 (1.2-PEL), 8237 (1.3-PEL), 8244 (3.2-PEL), 8245 (3.2-PEL), 8256 (3.2-PEL), 8296 (1.1-PEL), 8350 (2.3PEL), 8513 (1.1-PEL), 8526 (1.2-PEL), 8535 (3.2-PEL), 8554 (3.2-PEL), 8574 (2.3-PEL), 8641 (1.1-PEL), 8656 (3.2-PEL), 8657 (3.3-PEL), 8658 (1.3-PEL), 8749 (2.2PEL), 8803 (1.1-PEL), 8923 (1.1-PEL), 9064 (3.1-PEL), 9074 (3.1-PEL), 9170 (3.1-PEL), 9196 (1.1-PEL), 9250 (2.1-PEL), 9353 (1.1-PEL), 9363 (3.3-PEL), 9436 (1.1PEL), 9499 (2.3-PEL), 9534 (2.3-PEL). Teixeira, C: s.n. (2.1-ICN 112070). Trevisan, R: 889 (2.3-ICN), 891 (2.3-ICN), 954 (3.3-ICN). Valls, JFM: 1115 (2.1-ICN), 1384 (2.2-ICN), 1412 (1.2-ICN), 1480 (3.1-ICN), 1497 (3.3-ICN), 1593 (1.2-ICN), 2144 (2.1-ICN), 2667 (2.2ICN), 2676 (3.3-ICN), 2864 (3.3-ICN), 2910 (1.2-ICN), 2982 (2.3-ICN), 3095 (3.1-ICN), 3096 (3.3-ICN), 3110 (3.2-ICN), 3285 (2.1-ICN), 3291 (2.2-ICN), 4342 (3.1ICN), 4598 (1.1-ICN), 4619 (3.1-ICN). Waechter, JL: 745 (3.2-HAS), 1019 (2.1-ICN). Wasum, R: 495 (1.3HUCS), 1338 (1.1-HUCS), 1339 (1.1-HUCS). Welker, CAD: 57 (3.1-ICN), 87 (3.3-ICN), 117 (1.1-ICN), 158 (2.1-ICN), 169 (3.1-ICN), 173 (2.1-ICN), 174 (2.1ICN), 175 (2.1-ICN), 176 (2.1-ICN), 179 (2.1-ICN), 182 (1.3-ICN), 183 (1.1-ICN), 186 (3.1-ICN), 188 (3.1ICN), 197 (3.3-ICN), 211 (1.1-ICN), 214 (3.3-ICN), 215 (3.1-ICN), 219 (2.3-ICN), 222 (3.3-ICN), 229 (3.3ICN), 232 (3.1-ICN), 241 (2.3-ICN), 243 (1.3-ICN), 245 (2.1-ICN), 247 (2.1-ICN), 249 (2.1-ICN), 252 (3.3ICN), 253 (1.1-ICN), 259 (3.1-ICN), 260 (3.1-ICN), 269 (3.1-ICN), 270 (3.1-ICN), 287 (2.1-ICN), 290 (1.1ICN), 293 (3.3-ICN), 294 (3.1-ICN), 295 (3.2-ICN), 297 (2.3-ICN), 302 (3.3-ICN), 304 (3.3-ICN), 305 (1.1ICN), 306 (3.3-ICN), 307 (3.3-ICN), 312 (3.2-ICN), 313 (3.2-ICN), 315 (3.2-ICN), 316 (3.2-ICN), 317 (3.1ICN), 318 (3.3-ICN), 322 (3.3-ICN), 327 (3.3-ICN), 328 (1.3-ICN), 337 (1.2-ICN), 338 (1.2-ICN). Windisch, PG: 9957 (3.1-PACA). Wood, JRI: 13071 (1.1-K). Záchia, R: 1121 (3.1-ICN). Zanin, A: 19 (1.3-ICN), 1179 (1.2-ICN). 